\title{
Detection of Panulirus argus Virus 1 (PaV1) in exported frozen tails of subadult-adult Caribbean spiny lobsters Panulirus argus
}

\author{
Juan Pablo Huchin-Mian ${ }^{1}$, Patricia Briones-Fourzán², Raúl Simá-Álvarez ${ }^{1}$, \\ Yanis Cruz-Quintana', Juan Antonio Pérez-Vega' ${ }^{1}$, Enrique Lozano-Álvarez ${ }^{2}$, \\ Cristina Pascual-Jiménez ${ }^{2,3}$, Rossanna Rodríguez-Canul ${ }^{1, *}$
}

\footnotetext{
${ }^{1}$ Laboratorio de Inmunología y Biología Molecular, Centro de Investigación y de Estudios Avanzados del Instituto Politécnico Nacional-Unidad Mérida, Km 6 Antigua Carretera a Progreso, CORDEMEX, Mérida, Yucatán 97310, Mexico

${ }^{2}$ Universidad Nacional Autónoma de México, Instituto de Ciencias del Mar y Limnología, Unidad Académica Puerto Morelos, Ap Postal 1152, Cancún, Quintana Roo 77500, Mexico

${ }^{3}$ Universidad Nacional Autónoma de México, Unidad Marina de Ciencias Interdisciplinarias Unidad Sisal, Yucatán 97355, Mexico
}

\begin{abstract}
The Caribbean spiny lobster Panulirus argus is a valuable fishing resource and the trade in frozen lobster tails is an important industry. However, the presence of the pathogenic virus Panulirus argus Virus 1 (PaV1), which causes systemic infection in $P$. argus and is particularly lethal to juvenile individuals, has not been previously examined in imported/exported lobster products. We used PCR assays to determine the presence of PaV1 in abdominal muscle tissue of 22 frozen P. argus tails exported from Belize to Mexico. Based on their size, the tails belonged to subadult-adult lobsters. Using specific primers targeted for PaV1 resulted in 11 tails showing a specific 499 bp band. The sequence of positive amplified fragments showed a high similarity to PaV1 (95\% identity with GenBank accession no. EF206313.1). Although the pathogenicity of PaV1 was not evaluated in the present study, our results provide the first evidence of PaV1 in frozen lobster tails exported in the seafood industry as well as the first molecular evidence of PaV1 in adult lobsters.
\end{abstract}

KEY WORDS: Panulirus argus Virus $1 \cdot$ Frozen lobster tails · Caribbean Sea

\section{INTRODUCTION}

Spiny lobsters (Crustacea: Palinuridae) are highly valuable seafood, and the trade in live lobsters and frozen lobster products is an important industry for many countries. Recently, however, the Caribbean spiny lobster Panulirus argus has been affected by a highly pathogenic virus known as Panulirus argus Virus 1 (PaV1) (Shields \& Behringer 2004). PaV1 is an unclassified virus that is infectious and lethal to juvenile $P$. argus (Shields \& Behringer 2004, Huchin-Mian et al. 2008). PaV1 is a large unenveloped, icosahedral
DNA virus with a nucleocapsid of $\sim 187 \mathrm{~nm}$ in size that causes systemic infection, as evidenced by selective destruction of hyalinocytes and semigranulocytes, lack of hemolymph coagulation, and irreversible structural damage to the hepatopancreatic tissues (Shields \& Behringer 2004, Li et al. 2008). In the laboratory, PaV1 has been transmitted among lobsters by inoculation, contact, and ingestion of infected tissues, and over short distances in the water (Butler et al. 2008). Lobsters challenged with PaV1 develop clinical signs of the disease within 30 to $80 \mathrm{~d}$. These signs include lethargy, suppression of molt, a pink discoloration of 
the clear marks of the exoskeleton, and milky hemolymph (Shields \& Behringer 2004, LozanoÁlvarez et al. 2008). PaV1 has been reported in wild juvenile $P$. argus from Florida, Mexico, and the US Virgin Islands (Shields \& Behringer 2004, Huchin-Mian et al. 2008) and, according to Butler et al. (2008), outbreaks of PaV1 have resulted in mortalities of juvenile lobsters reared in mariculture research facilities in Florida, the Bahamas, and Belize. Thus, PaV1 appears to be widespread in the Caribbean, and given its high level of pathogenicity, it is considered a serious threat to local lobster fisheries throughout the Caribbean region (Butler et al. 2008, Lozano-Álvarez et al. 2008, Briones-Fourzán et al. 2009). Currently, available tools for detecting PaV1 in live lobsters include histological examination and PCR assays (Shields \& Behringer 2004, Montgomery-Fullerton et al. 2007, Huchin-Mian et al. 2008, Li et al. 2008), as well as fluorescence in situ hybridization (Li et al. 2006) and cell-culture assays (Li \& Shields 2007).

Many Caribbean countries export frozen lobster products to countries around the world. Due to the detrimental effects of PaV1 in Panulirus argus and the paucity of information regarding its infectivity for other species of lobsters and other crustaceans, its presence in imported/exported lobsters warrants investigation. The objective of the present study was to determine the presence of PaV1 in exported frozen tails of $P$. argus by means of PCR assays (Montgomery-Fullerton et al. 2007) and a DNA homology search in GenBank.

\section{MATERIALS AND METHODS}

Biological samples. Three packages containing 22 frozen tails of Panulirus argus exported from Belize to Mexico were forwarded by the Mexican customs office to our laboratory facilities (Centro de Investigación y de Estudios Avanzados del Instituto Politécnico Nacional [CINVESTAV-IPN]-Unidad Mérida) to perform sanitary analyses in accordance with the Mexican regulations for importation/exportation of live and/or frozen commodity crustaceans (NOM-EM-006-PESC2004). Although screening for PaV1 is not presently included in the Mexican regulations, we examined the abdominal (tail) muscles for the presence of PaV1.

Of the 3 packages that we received, 2 contained 7 tails each and the other contained 8 tails. After thawing at ambient temperature for $1 \mathrm{~h}$, the tails were sexed by observation of the abdominal appendages (pleopods), which are larger and biramous in females and smaller and uniramous in males. Each tail was extended on a flat surface and measured ventrally to the nearest millimeter from the anterior end of the first abdominal somite to the posterior end of the telson (abdominal length, $\mathrm{AL}$, in $\mathrm{mm}$ ). The $\mathrm{AL}$ was converted to carapace length $(\mathrm{CL}, \mathrm{mm})$ using the equations derived by Padilla-Ramos \& Briones-Fourzán (1997) from 207 Panulirus argus lobsters (size range: 62.0 to $163.0 \mathrm{~mm} \mathrm{CL}$ ) from the Mexican Caribbean, i.e. females: $\mathrm{CL}=(\mathrm{AL}-$ 23.477)/1.571, males: $\mathrm{CL}=(\mathrm{AL}-29.288) / 1.398)$.

The lobster tails were not individually wrapped and the muscle from the first abdominal somite was partially exposed; therefore, we avoided taking samples from this potentially contaminated area. Instead, a portion of muscle was extracted from a depth of $\sim 1 \mathrm{~cm}$ from the ventral side of the second or third abdominal somite. All samples were obtained with sterile blades and scissors. To prevent cross-contamination, necropsy tools were rinsed and flame-sterilized using 95\% ethanol between sample collections.

PCR. DNA was extracted from $\sim 25 \mathrm{mg}$ of muscle tissue from all 22 lobster tails with the Wizard ${ }^{\circledR}$ genomic DNA purification kit (Promega) according to the manufacturer's protocol. Specific primers for PaV1, 45aF (TTC CAG CCC AGG TAC GTA TC) and 543aR (AAC AGA TTT TCC AGC AGC GT), that amplify a region of 499 bp were used in a 1-step PCR (MontgomeryFullerton et al. 2007). All PCR reactions were carried out in a total volume of $25 \mu \mathrm{l}$ containing $\sim 32.5 \mathrm{ng}$ of DNA, $0.33 \mu \mathrm{M}$ of each primer, $2.5 \mathrm{mM}$ of $\mathrm{MgCl}_{2}, 1.2 \times$ reaction buffer $(50 \mathrm{mM} \mathrm{KCl}, 10 \mathrm{mM}$ Tris- $\mathrm{HCl}, \mathrm{pH} 9.0$, $0.1 \%$ Triton X-100), $0.4 \mathrm{mM}$ dNTPs mixture (Promega), and $2.5 \mathrm{U}$ of Taq DNA polymerase (BioLabs). The PCR reactions were run on a thermal cycler (Techne TC312). The cycling conditions were $94^{\circ} \mathrm{C}$ for $10 \mathrm{~min}$, followed by 30 cycles of $94^{\circ} \mathrm{C}$ for $30 \mathrm{~s}, 63^{\circ} \mathrm{C}$ for $30 \mathrm{~s}$, and $72^{\circ} \mathrm{C}$ for $1 \mathrm{~min}$, with a final extension of $72^{\circ} \mathrm{C}$ for $10 \mathrm{~min}$. PCR products were run in a $2 \%$ agarose gel electrophoresis with a $100 \mathrm{bp}$ DNA ladder. Bands were visualized using $0.1 \%$ ethidium bromide stain on a UV documentation system (MiniBis Pro ${ }^{\circledR}$ ). To increase the sensitivity of the PCR, $1 \mu \mathrm{l}$ of the first-round PCR product was used as a template for a second-round PCR (Montgomery-Fullerton et al. 2007). In all cases ultrapure water and tissue from non-infected lobsters were used as negative controls, whereas DNA from a highly infected lobster (Grade 4 infection) was used as a positive control (Huchin-Mian et al. 2008). We did not use an internal lobster control for the PCR assays such as amplification of lobsters' beta-actin gene as performed by Hasson et al. (2006). All PCR analyses were done in triplicate and positive fragments were forward- and reverse-sequenced at the CINVESTAV IPN-Unidad Irapuato. Sequences were checked and aligned using the CLUSTALW option in the MEGA4 software (Tamura et al. 2007). Similarity in the consensus sequence was searched in GenBank using the basic local alignment search tool (BLAST) (http://blast.ncbi. nlm.nih.gov). 
Table 1. Panulirus argus. PCR assays to test for the presence of $P$. argus Virus 1 in abdominal muscle tissue from 22 exported tails of spiny lobster. Data are arranged by lobster sex and by increasing size. +: tested positive; -: tested negative; F: female; M: male; AL: abdominal length; CL: carapace length, estimated from $\mathrm{AL}$

\begin{tabular}{|c|c|c|c|c|c|}
\hline \multirow{2}{*}{$\begin{array}{l}\text { Tail } \\
\text { number }\end{array}$} & \multirow[t]{2}{*}{ Sex } & \multirow{2}{*}{$\begin{array}{c}\mathrm{AL} \\
(\mathrm{mm})\end{array}$} & \multirow{2}{*}{$\begin{array}{c}\mathrm{CL} \\
(\mathrm{mm})\end{array}$} & \multicolumn{2}{|c|}{ PCR } \\
\hline & & & & 1 st round & 2nd round \\
\hline 7 & F & 129 & 67.2 & + & + \\
\hline 4 & $\mathrm{~F}$ & 137 & 72.3 & - & - \\
\hline 6 & F & 139 & 73.5 & - & + \\
\hline 10 & F & 139 & 73.5 & - & + \\
\hline 1 & $\mathrm{~F}$ & 144 & 76.7 & - & - \\
\hline 20 & $\mathrm{~F}$ & 152 & 81.8 & - & - \\
\hline 8 & F & 154 & 83.1 & - & - \\
\hline 14 & F & 158 & 85.6 & - & - \\
\hline 5 & F & 159 & 86.3 & - & + \\
\hline 18 & F & 162 & 88.2 & - & - \\
\hline 12 & F & 192 & 107.3 & + & + \\
\hline 3 & M & 130 & 72.0 & - & - \\
\hline 11 & M & 130 & 72.0 & + & + \\
\hline 22 & M & 130 & 72.0 & + & + \\
\hline 19 & M & 145 & 82.8 & - & - \\
\hline 21 & M & 155 & 89.9 & - & - \\
\hline 2 & M & 156 & 90.6 & - & - \\
\hline 9 & M & 160 & 93.5 & - & + \\
\hline 16 & $\mathrm{M}$ & 161 & 94.2 & + & + \\
\hline 17 & $\mathrm{M}$ & 163 & 95.6 & - & + \\
\hline 15 & M & 164 & 96.4 & - & - \\
\hline 13 & M & 190 & 115.0 & + & + \\
\hline
\end{tabular}

\section{RESULTS}

Eleven of the 22 tails examined belonged to females (129 to $192 \mathrm{~mm} \mathrm{AL}$, corresponding to 67.2 to $107.3 \mathrm{~mm}$ $\mathrm{CL}$ ) and 11 belonged to males (130 to $190 \mathrm{~mm} \mathrm{AL}$, corresponding to 72.0 to $115.0 \mathrm{~mm} \mathrm{CL}$ ) (Table 1). Given their size, these tails belonged to subadult and adult lobsters. In total, 11 tails tested positive for PaV1 in the PCR assays. In the first round, muscle tissue from 6 tails showed a faint band at $499 \mathrm{bp}$. In the second round, the same organisms, plus 5 more organisms, showed a stronger band at $499 \mathrm{bp}$. (Table 1). The BLAST analysis of the amplified sequences submitted to GenBank revealed a $95 \%$ homology to the genome of PaV1 (accession no. E206313.1) (Montgomery-Fullerton et al. 2007).

\section{DISCUSSION}

Our results provide the first evidence of the presence of PaV1 in exported frozen tails of Panulirus argus lobsters. Of the 22 tails examined, 11 tested positive for PaV1 in PCR assays. Histological examination of preserved tissues originating from live or moribund lobsters is an effective diagnostic tool for detecting PaV1, and the results are usually consistent with those gener- ated by other alternate diagnostic techniques such as PCR (Montgomery-Fullerton et al. 2007, Huchin-Mian et al. 2008), fluorescence in situ hybridization (Li et al. 2006), and cell-culture assays (Li \& Shields 2007). In the present study, presumptive Cowdry Type A intranuclear inclusion bodies were detected in 2 frozen tails by routine histology (data not shown), indicating the putative presence of PaV1. However, the interpretation of lesions in histological sections prepared from frozen tissues is presumptive at best (Rajendran et al. 1999) due to post-mortem tissue degeneration and/or freeze-thaw artifact. If histology is performed, putative positive histological findings for PaV1 in frozen lobster tails should be confirmed by one of the other diagnostic methods. The present results show that PCR detection of PaV1 is very reliable.

The PaV1 disease, which was first discovered in Florida, USA, in 1999 (Shields \& Behringer 2004), is currently widespread throughout the Caribbean (Butler et al. 2008, Lozano-Álvarez et al. 2008). This disease is particularly lethal to juvenile Panulirus argus lobsters, especially to the smaller, early benthic juveniles (EBJ; $<20 \mathrm{~mm} \mathrm{CL}$ ). In lobsters experimentally challenged with PaV1, mortality rates were higher for EBJ than for larger juveniles (Butler et al. 2008). Although disease prevalence has been reported to decrease as lobster size increases (Shields \& Behringer 2004, LozanoÁlvarez et al. 2008, Briones-Fourzán et al. 2009), the prevalence of PaV1 in wild adult lobsters, which occupy different habitats than juvenile lobsters, has not been well studied. In Florida, Shields \& Behringer (2004) reported a $<1 \%$ prevalence of individuals with signs of overt infection in a population of subadultadult lobsters. However, to our knowledge, our results provide the first molecular evidence of PaV1 in tails belonging to subadult and adult $P$. argus lobsters that showed no overt clinical signs of PaV1 infection, contrary to the findings of Shields \& Behringer (2004). This finding is significant because it may indicate that the virus can be present in potentially asymptomatic subadults and adults, which are the only age groups of Caribbean spiny lobsters that are legally exported so as to protect younger stocks from over-fishing. As a result, the potential exists for the spread of the disease to other countries via these animals. In $P$. argus lobsters infected with PaV1, the earliest sites of infection include the hepatopancreas and heart, which are located in the cephalothorax. In later stages of the infection, cells of the spongy connective tissues supporting the abdominal muscles or surrounding the hindgut also become infected (Li et al. 2008). However, because PCR assays can detect infections that may not be associated with pathology (Montgomery-Fullerton et al. 2007), our detection of PaV1 in $50 \%$ of the frozen tails that we examined must be assessed with more refined techniques, 
such as cell-culture assays (Li \& Shields 2007) or realtime PCR, to quantify the viral load and determine infection severity.

Previous studies have detected the presence of pathogenic viruses such as infectious hypodermal hematopoietic necrosis virus (IHHNV), white spot syndrome virus (WSSV), yellow head virus (YHV), and Taura syndrome virus (TSV) in frozen products from several shrimp species imported into the USA and Australia (Nunan et al. 1998, Durand et al. 2000, Reville et al. 2005, Hasson et al. 2006, Ueda et al. 2008). In some cases the viruses isolated from the frozen products were found to be viable and infectious, leading the researchers to speculate that these diseases could potentially spread to other countries through exports (Nunan et al. 1998, Durand et al. 2000, Hasson et al. 2006). Although this notion was recently challenged due to lack of epidemiological analyses (Flegel 2009), it has not been discounted and is still a cause for concern. Similar to most shrimp viruses, PaV1 appears to have a high degree of host specificity and appears to pose little risk to other marine crustaceans (Butler et al. 2008). However, this issue also warrants further investigation.

Our results provide the first evidence of PaV1 in frozen lobster products and the first molecular evidence of PaV1 in subadult and adult Panulirus argus lobsters. Subjects for future study include determination of the viral load in these products and assessing the viability of PaV1 in frozen lobster tails. Such studies would increase our understanding of PaV1 and of the nature of the disease caused by this relatively new pathogen.

Acknowledgements. We thank Consejo Nacional de Ciencia y Tecnologia (CONACyT) for providing a postgraduate studentship to J.P.H.M. (grant no. 190532). Special thanks to C. Barradas-Ortiz, F. Negrete-Soto, and T. Ruíz-Ruz for their invaluable technical support. This study was financed through external services performed at the Laboratory of Immunology and Molecular Biology, CINVESTAV IPN Unidad Mérida (reference no. A3329).

\section{LITERATURE CITED}

Briones-Fourzán P, Baeza-Martínez K, Lozano-Álvarez E (2009) Nutritional indices of juvenile Caribbean spiny lobsters in a Mexican reef lagoon: Are changes over a 10-year span related to the emergence of Panulirus argus Virus 1 (PaV1)? J Exp Mar Biol Ecol 370:82-88

Butler MJ, Behringer DC, Shields JD (2008) Transmission of Panulirus argus virus 1 (PaV1) and its effect on the survival of juvenile Caribbean spiny lobster. Dis Aquat Org 79:173-182

Durand SV, Tang KFJ, Lightner DV (2000) Frozen commodity shrimp: potential avenue for introduction of white spot syndrome virus and yellow head virus. J Aquat Anim Health 12:128-135

Flegel TW (2009) Review of disease transmission risks from prawn products exported for human consumption. Aquaculture 290:179-189

Hasson KW, Fan Y, Reisinger T, Venuti J, Varner PW (2006) White-spot syndrome virus (WSSV) introduction into the Gulf of Mexico and Texas freshwater systems through imported, frozen bait-shrimp. Dis Aquat Org 71:91-100

Huchin-Mian JP, Rodriguez-Canul R, Arias-Bañuelos E, SimáÁlvarez R, Pérez-Vega JA, Briones-Fourzán P, LozanoÁlvarez E (2008) Presence of Panulirus argus Virus 1 (PaV1) in juvenile spiny lobsters Panulirus argus from the Caribbean coast of Mexico. Dis Aquat Org 79:153-156

Li C, Shields JD (2007) Primary culture of hemocytes from the Caribbean spiny lobster, Panulirus argus, and their susceptibility to Panulirus argus Virus 1 (PaV1). J Invertebr Pathol 94:48-55

Li C, Shields JD, Small HJ, Reece KS, Hartwig CL, Cooper RA, Ratzlaff RE (2006) Detection of Panulirus argus Virus 1 (PaV1) in the Caribbean spiny lobster using fluorescence in situ hybridization (FISH). Dis Aquat Org 72: 185-192

Li C, Shields JD, Ratzlaff RE, Butler MJ (2008) Pathology and hematology of Caribbean spiny lobsters experimentally infected with Panulirus argus virus 1 (PaV1). Virus Res 132:104-113

Lozano-Álvarez E, Briones-Fourzán P, Ramírez-Estévez A, Placencia-Sánchez D, Huchin-Mian JP, Rodríguez-Canul R (2008) Prevalence of Panulirus argus Virus 1 (PaV1) and habitation patterns of healthy and diseased Caribbean spiny lobsters in shelter-limited habitats. Dis Aquat Org 80:95-104

Montgomery-Fullerton MM, Cooper RA, Kauffman KM, Shields JD, Ratzlaff RE (2007) Detection of Panulirus argus Virus 1 in Caribbean spiny lobsters. Dis Aquat Org 76:1-6

> Nunan LM, Poulos BT, Lightner DV (1998) The detection of white spot syndrome virus (WSSV) and yellow head virus (YHV) in imported commodity shrimp. Aquaculture 160: 19-30

Padilla-Ramos S, Briones-Fourzán P (1997) Biological characteristics of the spiny lobsters (Panulirus spp.) from the commercial catch in Puerto Morelos, Quintana Roo, Mexico. Cienc Mar 23:175-193

> Rajendran KV, Vijayan KK, Santiago TC, Krol RM (1999) Experimental host range and histopathology of white spot syndrome virus (WSSV) infection in shrimp, prawns, crabs, and lobsters from India. J Fish Dis 22:183-191

Reville C, Al-Beik J, Meehan-Mola D, Xu Z, Goldsmith ML, Rand W, Alcívar-Warren A (2005) White spot syndrome virus in frozen shrimp sold at Massachusetts supermarkets. J Shellfish Res 24:285-290

Shields JD, Behringer DC (2004) A new pathogenic virus in the Caribbean spiny lobster Panulirus argus from the Florida Keys. Dis Aquat Org 59:109-118

Tamura K, Dudley J, Nei M, Kumar S (2007) MEGA4: molecular evolutionary genetic analysis (MEGA) software version 4.0. Mol Biol Evol 24:1596-1599

Ueda R, Krabsetsve K, Owens L (2008) Polymerase chain reaction detection of Taura syndrome virus and infectious hypodermal and haematopoietic necrosis virus in frozen commodity tails of Penaeus vannamei Boone. Aquacult Res 39:1606-1611 